\title{
Ebola: DRC's declaration of victory over outbreak is postponed after new deaths
}

\section{Owen Dyer}

Montreal

The Democratic Republic of the Congo's (DRC) worst ever Ebola outbreak is back on, at least temporarily, after new cases appeared just hours before the country passed a 42 day disease-free landmark, which normally marks the end of an outbreak.

To declare an Ebola outbreak over, two incubation periods-equal to 42 days - must have passed since the last case was active. The last known survivor tested negative on 3 March, so the 42 days were due to finish on 13 April.

But on 10 April a 26 year old electrician in Beni, North Kivu province, fell ill and died soon afterwards. The death of an 11 month old girl from Ebola was announced on 12 April, and a 7 year old girl has also tested positive and is undergoing treatment. The three patients did not know each other, but all had visited the same clinic, said Boubacar Diallo, deputy incident manager for the World Health Organization's Ebola response, speaking to Reuters. The virus can survive on medical instruments for weeks.

Tedros Adhanom Ghebreyesus, WHO director general, said, "While not welcome news, this is an event we anticipated. We kept response teams in Beni and other high risk areas for precisely this reason."
Officials remain optimistic that the virus will not surge again, partly because over 300000 people have now been vaccinated. "We think we will quickly contain this outbreak," said Diallo.

The North Kivu Ebola outbreak is surpassed in scale only by the great west African epidemic of 2014, which killed over 11 000 people. The worst of 11 outbreaks in DRC, it has infected at least 3456 people and killed 2276 since August 2018. Health workers have struggled against local suspicion, armed gangs, and even deadly attacks on clinics in the country's troubled north east.

The delay in vanquishing Ebola came just as health workers were pivoting to tackle the novel coronavirus, which has been detected in 235 people so far in the DRC. But the Ebola work would now go on, Michael Ryan, head of WHO's health emergency committee, told VOA News.

He said, "Every day, we investigate 2600 alerts across the two affected provinces still. We take thousands of samples every single week, and we will continue that active surveillance right the way through. We will just have to go again for another 42 days." 